\title{
Role of Perceived Importance of Information Security: An Exploratory Study of Middle School Children's Information Security Behavior
}

\author{
S. Chai and S. Bagchi-Sen \\ University at Buffalo, SUNY, \\ Buffalo, NY, USA \\ schai2@buffalo.edu \\ geosbs@buffalo.edu
}

\author{
C. Morrell \\ University of Maryland at \\ Baltimore County, Baltimore, \\ MD, USA \\ cmorrell@umbc.edu
}

\author{
H. R. Rao and S.Upadhyaya \\ University at Buffalo, SUNY, Buffalo, NY, USA \\ mgmtrao@buffalo.edu shambhu@buffalo.edu
}

\begin{abstract}
Information security and privacy on the Internet are critical issues in our society. Importantly, children and adolescents need to understand the potential risk of using the Internet. In this research, we examine factors that motivate students' Information Security Behavior on the Internet. A pilot survey of middle and junior high school students is the source of the data. This study provides a model that explains students' behavior pertaining to Information Security. A significant research finding is that students' perceived importance of Information Security plays a critical role in influencing their Information Security Behavior.
\end{abstract}

Keywords: Information Security, Self-efficacy, Internet, Perceived Importance, Information Security Behavior.

\section{Introduction}

In recent years a large number of children have started to regularly use the Internet at home, at school, in libraries, and community centers. With this proliferation of use, information and computer security are becoming important issues. We see this in various forms: in the prevention of crime (e.g., physical molestation), harassment and bullying on the Internet, as well AS damage from computer viruses and the breach of privacy.

Material published as part of this publication, either on-line or in print, is copyrighted by the Informing Science Institute. Permission to make digital or paper copy of part or all of these works for personal or classroom use is granted without fee provided that the copies are not made or distributed for profit or commercial advantage AND that copies 1 ) bear this notice in full and 2) give the full citation on the first page. It is permissible to abstract these works so long as credit is given. To copy in all other cases or to republish or to post on a server or to redistribute to lists requires specific permission and payment of a fee. Contact Publisher@InformingScience.org to request redistribution permission.
The Conference Board and TNS, the world's largest custom research company, produced a survey to measure the Consumer Internet Barometer, which covers 10,000 households (2005). This survey shows that approximately 41 percent of online households include school-age children (enrolled in Kindergarten through college). It also reveals that only 56 percent of parents are confident that their kids view only age- 
appropriate content when logging on from the classroom. Another $50 \%$ of parents also worry about privacy and identity theft of their children (2005). Often, the children are, in general, far ahead of their parents in terms of Internet usage since they use blogs and instant messaging to keep in touch with their friends. The teenagers who responded to the Conference Board survey said that they were usually able to circumvent many computer security measures at school (Lemos, 2005). Clearly, this shows that motivating kids to keep their safety on the Internet is more important than supervising and enforcing information security on the Internet.

In this research, we carry out pilot research in order to attempt to understand the factors that motivate school-age children to pay attention to Information Security and motivate them to use the Internet safely. We use social cognitive theory to introduce Information Security Self-Efficacy, Perceived Information Security Importance, and Exposure of Information Security as important factors in influencing the attitude of middle school children's toward information security.

\section{Theoretical Background and Hypothesis}

\section{Social Cognitive Theory and Self-Efficacy}

Social cognitive theory (Bandura, 1986) is widely used to explain individual behavior. It premises that personal factors in the form of cognitive, affective and biological events, behavior and environmental events all operate as interacting determinants that influence each other (Bandura, 1986). According to this theory, an individual chooses the environment in which they exist in addition to being influenced by that environment. Furthermore, both behavior in a given situation and the environment affect each other. Finally, behavior is influenced by cognitive and personal factors (Compeau \& Higgins, 1995). In this reciprocal relationship among environment, behavior and individual, Bandura(1986) introduces self-efficacy as a major cognitive force guiding individual behavior. He defines self-efficacy as people's judgment of their capabilities to perform a task. Self-efficacy is concerned with judgments of what one can do and not with skills (Bandura 1986).

Self-efficacy beliefs perform as an important set of proximal determinants of human motivation and action. They operate on personal behavior through motivational, cognitive, and affective intervening processes (Bandura, 1989). Bandura, Barbaranelli, Caprara, and Pastorelli (1996) show that children's academic self-efficacy is positively associated with their academic performance.

In the context of IT, the research suggests that individuals who possess high self-efficacy toward IT use IT more frequently (Compeau, Higgins, \& Huff, 1999). People who have higher level of self-efficacy toward a specific subject are more like to give greater value to that subject. Wisenbaker, Scott and Nasser (2000) show that students' strong cognitive competency toward statistics is related to more value for statistics. In the child development context, children's task-specific beliefs regarding their own ability influence their values regarding a subject (Wigfield \& Eccles, 2000).For example, a child, who believes he or she can do well at math, tends to value mathematics more than a child who does not have belief in his or her math competence.

Previous research shows children are much more likely to value math, language, art, and sports when they feel competent in the domain (Jacobs, Lanza, Osgood, Eccles, \& Wigfield, 2002). Based on previous research findings, we assume that students who have more opportunity to learn about information security from school, parents and friends would have stronger self-efficacy in information security. Furthermore, if students are exposed to information security, then they tend to have strong perceived importance of information security. In other words, if students hear about information security issues such as how to protect privacy on the Internet or avoid risks from computer viruses, they will develop better perception of information security on the Internet. Based on these assumptions, the hypotheses are: 
H1a: Information Security Exposure has positive effect on perceived Information Security Self-Efficacy

H1b: Information Security Exposure has positive impact on Information Security behavior

H1c: Information Security Exposure has positive effect on Perceived Information Security Importance

Based on previous studies regarding self-efficacy, we propose that if students have high selfefficacy toward information security behavior, such as keeping personal information private during Internet use and protecting computers from computer viruses, they will have a strong motivation to implement behavior that shows sensitivity to information security. Furthermore, students are more likely to value information security when they have a high level of self-efficacy in the information security domain. Here we propose the following hypothesis.

H2: Perceived Information Security self-efficacy has positive effect on Perceived Information Security Importance

\section{Perceived Importance of Information Security}

As one of the factors driving individual motivation to perform a behavior, such as an academic task, perceived importance has been discussed in numerous studies. Pajares and Graham (1999) observe that middle school students who have high mathematics performance have high perceived importance of mathematics. In evaluating training programs, employee's perceived importance of the training program plays an important role in increasing motivation to join and do well in the training program (Tasi \&Tai, 2003). The value, or importance of the object or activity, has positive relationship with individual motivation (Eccles \& Wigfield, 2002).

We propose that students who have high perceived importance of information security will have more motivation to be proactive in their information security behavior.

Hypothesis 3: Perceived Information Security Importance has positive effect on Information Security Behavior

Our research model and definitions are presented Figure 1 and Table 1.

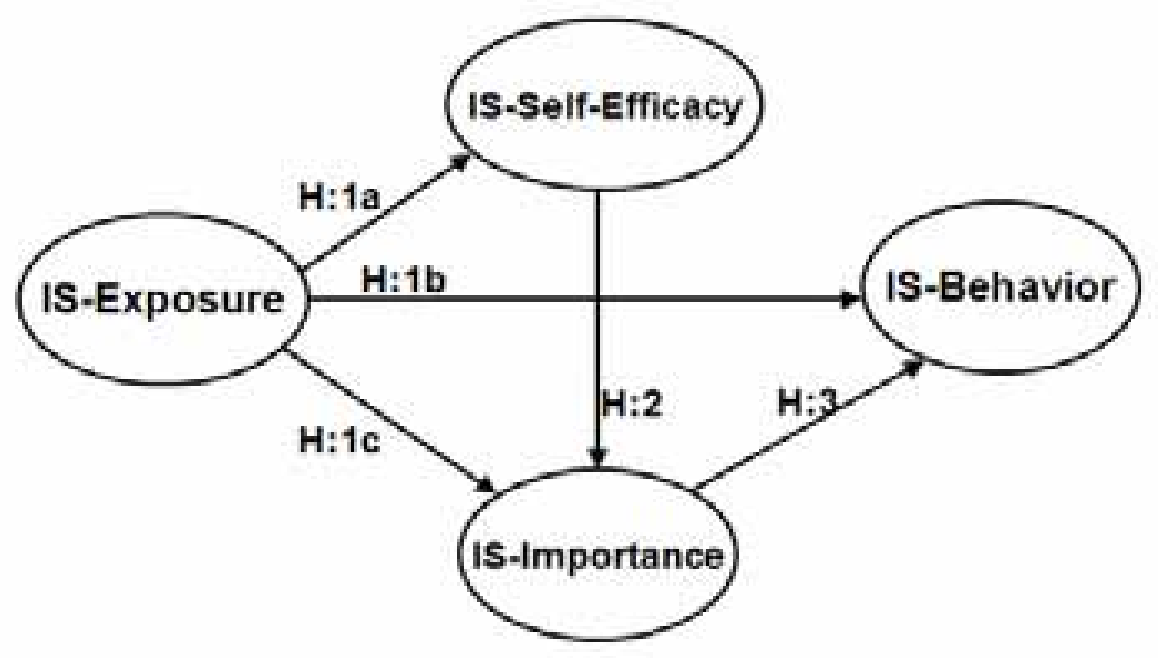

Figure 1 Research Model 
Table 1 Construct definition

\begin{tabular}{|c|l|}
\hline Construct & \multicolumn{1}{|c|}{ Definition } \\
\hline $\begin{array}{c}\text { Information Security } \\
\text { Exposure (IE) }\end{array}$ & $\begin{array}{l}\text { Experience of learning and hearing about information secu- } \\
\text { rity and privacy in using internet and computer }\end{array}$ \\
\hline $\begin{array}{c}\text { Information Security } \\
\text { Self-efficacy (IS) }\end{array}$ & $\begin{array}{l}\text { Individuals’ judgment of their capabilities to perform in- } \\
\text { formation security behavior }\end{array}$ \\
\hline $\begin{array}{c}\text { Perceived Information Security } \\
\text { Importance (ISI) }\end{array}$ & $\begin{array}{l}\text { Individuals’ perceived importance of information security } \\
\text { behavior }\end{array}$ \\
\hline Information Security Behavior & $\begin{array}{l}\text { User’s behavior to protect their privacy and computer from } \\
\text { virus ( e.g., Updating anti-virus software, Never opening e- } \\
\text { mail from unknown senders and Updating computer operat- } \\
\text { ing system regularly etc.) }\end{array}$ \\
\hline
\end{tabular}

\section{Research Design and Methodology}

\section{Research design and Sample}

This pilot study uses survey methodology to gather data. The sample size is 33. A sample is drawn from $6^{\text {th }}$ to $9^{\text {th }}$ grade students, who attended a summer technology camp at Baltimore, Maryland in July, 2005. 20\% of the respondents were male students and $80 \%$ of the respondents were female students.

\section{Measures of the construct}

We use measures that have been validated in previous research to ensure the control of measurement errors. However, we do construct some measures to reflect the context of information security. Self-efficacy measures are adopted from self-efficacy literature in educational psychology (Bandura et al., 1996; Choi, Fuqua \& Griffin, 2001). Perceived importance measures are borrowed from Pajares and Graham (1999). These adopted measures are modified to reflect the context of information security. Other measures in the analysis are newly constructed for this study. Construct validity as well as structural coefficients are analyzed by PLS Graph v.03.

\section{Data Analysis}

\section{Model Testing and Construct Validity}

To test the model, we used Partial Least Square (PLS), a Structural Equation Modeling (SEM) Technique. PLS enables the specification of both the relationships among the constructs and the measures underlying each construct (Wold 1989).Most of the standardized loadings of individual item were over the acceptable cutoff level of 0.6 (Chin, 1998 a). The only loading lower than 0.6 was 0.5971 out of 15 reflective indicators (Table 2). Therefore, reliabilities of each item are acceptable.

The composite reliabilities, also referred to as a conversant validity, for the multiple reflective indicators in our model ranged from 0.778 (Information security Self-efficacy) to 0.900 (Information Security Exposure). They are well over the recommended acceptable level 0.7 (Fornell \& 
Larcker, 1981), which means that the measurement model secures construct level reliability. Composite reliability indexes are included in Table 3.

We tested discriminant validity by comparing Average Variance Extracted (AVE) and interconstruct correlation. All AVEs for the latent variables measured by reflective indicators are greater than the required minimum level of 0.5.and every construct had a square root of AVE bigger than its correlations with other constructs. This result presents that our measurement model ensures the discriminant validity (Chin, 1998b). Detailed AVE and inter-construct correlation coefficients are presented in Table 3.

Table 2 Measurement Items and Factor Loadings

\begin{tabular}{|c|c|}
\hline Information Security Behavior (IB) & $\begin{array}{l}\text { Factor } \\
\text { loadings }\end{array}$ \\
\hline IB1. I never open emails from unknown senders & 0.7203 \\
\hline $\begin{array}{l}\text { IB2. I never download files (like music, picture, game, movies, etc.) from the } \\
\text { Internet if the files are from unknown people. }\end{array}$ & 0.8050 \\
\hline $\begin{array}{l}\text { IB3. I never give my personal information (like home/email address, telephone } \\
\text { number, school name, etc.) to unknown websites. }\end{array}$ & 0.8297 \\
\hline IB4. I never give my personal information to people I first met on the Internet. & 0.8484 \\
\hline IB5. I pay attention to anti-virus updates every time I use a computer & 0.8289 \\
\hline \multicolumn{2}{|l|}{ Information Security Exposure (IE) } \\
\hline $\begin{array}{l}\text { IE.1 Have you ever heard how to protect your personal information and yourself } \\
\text { from other computer (or Internet) users? }\end{array}$ & 0.9091 \\
\hline $\begin{array}{l}\text { IE.2 Have you ever heard how to protect important information in your com- } \\
\text { puter from computer viruses? }\end{array}$ & 0.9091 \\
\hline \multicolumn{2}{|l|}{ Information Security Self-Efficacy (IS) } \\
\hline IS1. How good are you at making passwords difficult for others to guess? & 0.7173 \\
\hline $\begin{array}{l}\text { IS2. How good are you at keeping personal information (like name, photo, } \\
\text { email, address, telephone number, etc.) secret from other Internet users you } \\
\text { don't trust? }\end{array}$ & 0.5971 \\
\hline IS3. How good are you at protecting computers from computer viruses? & 0.7061 \\
\hline $\begin{array}{l}\text { IS4. How well are you aware of various computer/information security prob- } \\
\text { lems (like virus, privacy breach, bullying on the net, etc.)? }\end{array}$ & 0.7801 \\
\hline \multicolumn{2}{|l|}{ Information Security Importance (ISI) } \\
\hline $\begin{array}{l}\text { ISI1.How important is it to keep your personal information (like address, tele- } \\
\text { phone number, etc.) safe while using a computer? }\end{array}$ & 0.8589 \\
\hline ISI2.How important is it to protect computers you use from viruses? & 0.6324 \\
\hline $\begin{array}{l}\text { ISI3.How important is it to protect your privacy (like giving your name, email, } \\
\text { address, telephone number, etc.) on the Internet? }\end{array}$ & 0.8972 \\
\hline ISI4.How important is it for you to stay safe on the Internet? & 0.7925 \\
\hline
\end{tabular}


Table 3 Correlations, Composite Reliability and AVE of latent variables

\begin{tabular}{|c|l|c|c|c|c|c|}
\hline & \multicolumn{1}{|c|}{ IB } & IE & IS & ISI & $\begin{array}{c}\text { Composites } \\
\text { Reliability }\end{array}$ & AVE \\
\hline IB & 1.00 & & & & 0.896 & 0.634 \\
\hline IE & 0.104 & 1.000 & & & 0.900 & 0.819 \\
\hline IS & 0.085 & 0.218 & 1.000 & & 0.778 & 0.544 \\
\hline ISI & 0.244 & -0.330 & 0.359 & 1.000 & 0.873 & 0.634 \\
\hline
\end{tabular}

\section{Results}

For the evaluation of the structural model (hypothesized links), the bootstrap resampling procedure was applied to test the significance of the path coefficients. The path coefficient in the PLS model represents standardized regression coefficient. Standardized path coefficients should be around 0.20 and ideally above 0.30 in order to be considered meaningful (Chin, 1998b).

The results reveal that those path coefficients from Information Security Exposure to Information Security Self-efficacy and from Information Security Exposure to Information Security Importance are all positive and significant. In addition, path coefficients from Information Security Self-efficacy to Perceived Information Security Importance and from Perceived Information Security Importance to Information Security Behavior are also positive and significant.

In sum, $19 \%$ of the variance in students' Information Security Behavior is explained by our research model. However, Hypothesis H1a: Information Security Exposure has positive impact on information security behavior was not empirically supported in this study. The findings of hypotheses testing are summarized in Figure 2.

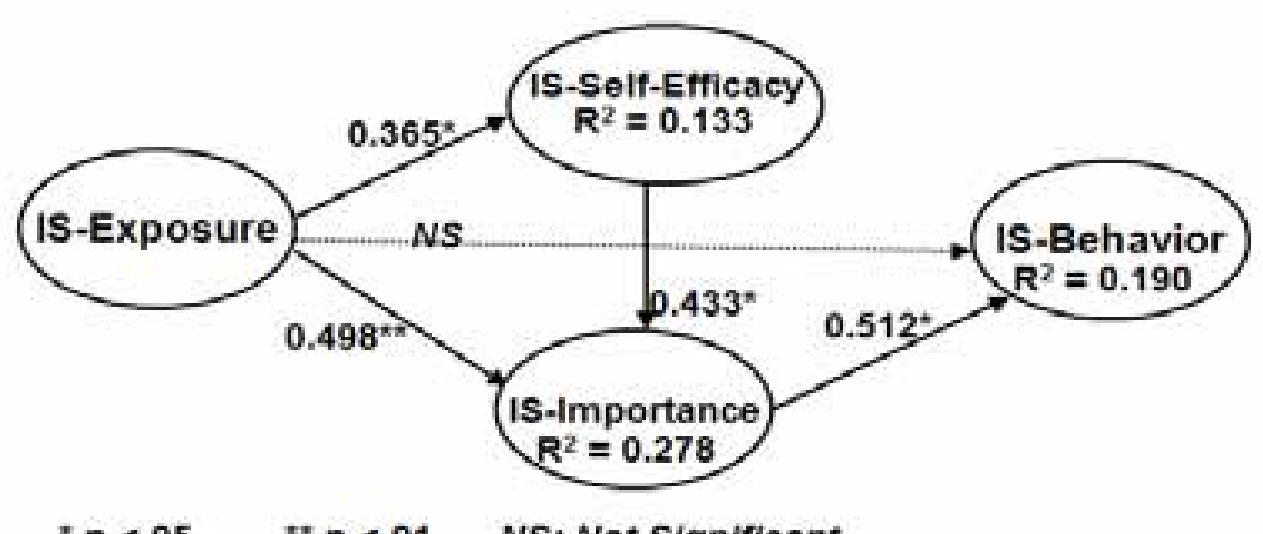

$* p<.05 \quad * p<.01 \quad$ NS: Not Significant

Figure 2 Structural Model Results

\section{Discussion and Limitations}

This pilot study focuses on social cognitive and self-efficacy theory to investigate Information Security behavior of $6^{\text {th }}-9^{\text {th }}$ grade students. These research findings suggest that students, who have strong self-efficacy toward Information Security on the Internet and have an exposure of 
information security from school, parents and media, are more likely to practice information security such as updating anti-virus software, not opening e-mails from unknown senders, and protecting personal information on the Internet.

To motivate students' information security behavior, we need to provide more information security education opportunities to students as well as chances for students to be exposed to information security issues. We also need to try to increase their Perceived Importance of information security.

Although we could confirm students' perceived importance toward Information Security on their Information Security Behavior, we fail to explain the direct relationship between Information Security Exposure and Information Security Behavior.

This failure seems to come from the fact that we have a small sample size since this is a pilot research study. The sample size in this study is 33 . To generate more statistically rigorous results, we shall conduct a further study using a bigger sample size. Another limitation is that we could not include more factors that can explain student's Information Security Behavior such as years of experience using internet and computer, length of education related with Information Security Issue and gender differences in our model. This limitation also comes from the limited sample size. Future research should be done with larger sample with more diverse demographic characteristic and additional factors.

\section{Acknowledgement}

This research has been funded by NSF under grant 0420448. The usual disclaimer applies.

\section{References}

Bagchi-Sen, S, Lee, JK. Rao, H. R., \& Upadhyaya, S. J. (2005). A framework for examining skill specialization, gender inequity, and career advancement in the information security field. Proceedings of the 1st International Conference On Information System Security. Kolkata, India.

Bandura, A. (1986). Social foundations of thought and action. New Jersey: Prentice Hall.

Bandura, A. (1989). Human agency in social cognitive theory. New Jersey: Prentice Hall.

Bandura, A., Barbaranelli, C., Caprara, G.V., \& Pastorelli, C. (1996). Multifaceted impact of self-efficacy beliefs on academic functioning. Child Development, 67(3), 1206-1222.

Banerjee, S., Kang, H., Bagchi-Sen, S., \& Rao, H. R. (2005). Gender divide in the use of the Internet applications. International Journal of E-Business Research, 1(2), 24-39.

Chin, W.W. (1998a). Issues and opinion on structural equation modeling. MIS Quarterly, 22(1), 7 - 16.

Chin, W.W. (1998b). The partial least squares approach for structural equation modeling. In G.A. Marcoulides (Ed), Modern methods for business research (pp. 295-336). New Jersey: Lawrence Erlbaum Associates Hillsdale.

Choi, N., Fuqua, D. R., \& Griffin, B. W. (2001), Exploratory analysis of the structure of scores from the multidimensional scales of perceived self-efficacy. Educational and Psychological Measurement, 61(3), 475-489.

Compeau, D., Higgins, C. A., \& Huff, S. (1999). Social cognitive theory and individual reactions to computing technology: A longitudinal Study. MIS Quarterly, 23(2), 145-158.

Compeau, D. R. \& Higgins, C. A. (1995). Computer self-efficacy: Development of a measure and initial test. MIS Quarterly, 19(2), 189-211.

Eccles, J.S. \& Wigfield, A. (2002). Motivational beliefs, values, and goals [Learning and performance in educational settings]. Annual Review Psychology, 53, 109-132. 
Fornell, C. \& Larcker, D. (1981). Evaluating structural equation models with unobservable variables and measurement error. Journal of Marketing Research, 18, 39-50.

Jacobs, J. E., Lanza, S., Osgood, D. W., Eccles, J. S. \& Wigfield, A.(2002). Changes in children's selfcompetence and values: gender and domain differences across grades one through twelve. Child Development, 73(2), 509-522.

Kang, H., Bachi-Sen, S., Rao, H. R., \& Banerjee, S.(2005). Internet skeptics: An analysis of intermittent users and net-dropouts. IEEE Technology and Society Magazine, 24, 26-31.

Lemos, R. (2005). Teenagers struggle with privacy, security issues. In SecurityFocus. Retrieved from http://www.securityfocus.com/news/10940

Pajares, F. \& Graham, L. (1999). Self-efficacy, motivation constructs, and mathematics performance of entering middle school students. Contemporary Educational Psychology, 24,124-139.

Parents concerned about Internet usage in the classroom. (2005). Newswise. Retrieved from http://www.newswise.com/articles/view/515310/

Tsai, W.-C. \& Tai, W.-T..(2003). Perceived importance as a mediator of the relationship between training assignment and training motivation. Personnel Review, 32(1/2), 151-163.

Wigfield, A. \& Eccles, J. S. (2000). Expectancy-value theory of achievement motivation. Contemporary Educational Psychology, 25(1), 68-.

Wisenbaker, J. M., Scott, J. S., \& Nasser, F. (2000). Structural equation models relating attitudes about and achievement in introductory statistics courses: A comparison of results from the U.S. and Israel. Ninth International Congress on Mathematics Education. Tokyo.1-8.

\section{Biographies}

Sangmi Chai is a PhD student at the State University of New York at Buffalo. She has an MBA from Seoul National University. Her research interests include information security, human computer interface, productivity of information technology, and women and minority work force in information technology and cyber security.

Sharmistha Bagchi-Sen is a professor of geography at the University at Buffalo (UB) and serves as the director of graduate studies in the Department of Geography. She currently teaches graduate and undergraduate courses in economic geography, labor markets, and international business. She received the Lilly Endowment teaching fellowship in 1991-1992. Her research interests are in the following areas: foreign direct investment; innovation and export market development by small and medium sized firms; geography of innovation in the biotechnology industry; and labor markets. She has published a number of articles on foreign direct investment in the United States export market development strategies by small and medium manufacturing firms (SMFs), and employment patterns. Three articles have been recently completed on the geography of innovation in the biotechnology industry. She has received research funding from the National Science Foundation (1998-1999, 2001-2004, 2004-2006) and the Canadian Embassy (1996-1997 and 1998-1999). She has served as an active member of the research team of three UB centers: Canada-U.S. Trade Center, Baldy Center for Law and Social Policy, and the National Center for Geographic Information Analysis. She is one of the advisory committee members for the Baldy Center for Law and Social Policy, and she served as a member of both the steering and executive committees for the Institute for Research and Education on Women and Gender at the University at Buffalo.

Claudia Morrell is Executive Director of the center for women and information technology at University of Maryland at Baltimore County. Under her leadership, the Center's programs and resources have expanded dramatically, including the development of a CWIT Scholars program which retains $94 \%$ of its students; increased funding of $\$ 7$ million in scholarships, research, and 
program funding to support girls' and women's participation and advancement in science, technology, engineering, and mathematics (STEM) careers in education and industry; and the expansion of personnel from two to forty-one staff, students, teachers, and faculty. She also served as the executive producer for an international award-winning women and technology video entitled, You Can Be Anything. Ms. Morrell effectively maintains an active 25-member advisory board with CEOs, CIOs, and high level executive women and men representing business, education and government leadership across the U.S. Currently she is directing several major initiatives that will increase the participation of girls and women in IT, from middle school through the college and university to the workforce and technology entrepreneurship. Ms Morrell was instrumental in drafting legislation that was signed in to law on May 26, 2004 that established the first statewide Governor's Taskforce on the Status of Women and IT, and she now serves as co-chair of the Taskforce. The Center's award-winning website, www.umbc.edu/cwit, is recognized internationally as "the best resource for women and IT on the web." Ms. Morrell speaks at state, national and international events, including recent presentations at the United Nations and World Bank. CWIT also hosted the first International Symposium on Women and IT in June 2005 in Baltimore, Maryland. Ms. Morrell serves on multiple statewide, national, and international advisory boards. Claudia Morrell received her Bachelor of Science degree from the University of North Carolina at Chapel Hill, a Master of Arts degree from Loyola College of Maryland, and a Master of Science degree from the University of Wisconsin, Madison. She lives in Maryland with her husband and three daughters. Her eldest daughter recently completed a computer science degree and is working in the field.

Dr. H. R. Rao's interests are in the areas of management information systems, decision support systems, and expert systems and information assurance. He has chaired sessions at international conferences and presented numerous papers. He has authored or co-authored more than 100 technical papers, of which more than 65 are published in archival journals. His work has received best paper and best paper runnerup awards at AMCIS and ICIS. Dr. Rao has received funding for his research from the National Science Foundation, the Department of Defense, and the Canadian Embassy, and he has received the University's prestigious Teaching Fellowship. He has also received the Fulbright fellowship in 2004 at York U, Ca. He is a co-editor of a special issue of The Annals of Operations Research, the Communications of ACM, associate editor of Decision Support Systems, Information Systems Research and IEEE Transactions in Systems, Man and Cybernetics, and co-editor- in -chief of Information Systems Frontiers.

Shambhu J. Upadhyaya is an Associate Professor of Computer Science and Engineering at the State University of New York at Buffalo where he also directs the Center of Excellence in Information Systems Assurance Research and Education (CEISARE), designated by the National Security Agency. He is an associate editor of IEEE Transactions on Computers, a member of the editorial board of the International Journal on Reliability, Quality, and Safety Engineering published by the World Scientific Publishers. He was a guest co-editor of the book series Interfaces in OR/CS on Mobile Computing: Implementing Pervasive Information and Communication Technologies, Kluwer Academic Publishers, 2001 and is a guest co-editor of a special issue on Secure Knowledge Management in IEEE Transactions on Systems, Man and Cybernetics, March 2006. He was on the Program Committee of 3rd IEEE International Information Assurance Workshop, Washington DC, March 2005, 6th Annual IEEE Information Assurance Workshop, West Point, NY, June 2005, and Dependable Computing and Communications Symposium of IEEE DSN-2005, among others. He is a senior member of IEEE. 